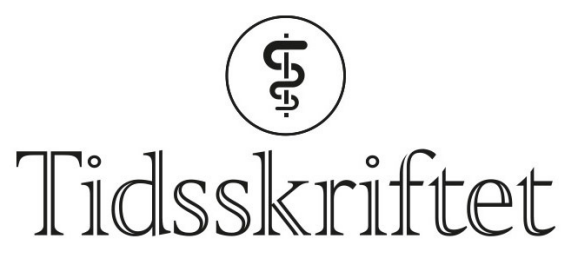

DEN NORSKE LEGEFORENING

\title{
Hva Richard Doll kan lære oss om smarttelefoner
}

ESSAY

\section{ANDERS MALKOMSEN}

E-post: anders.malkomsen@gmail.com Anders Malkomsen er lege med spesialisering i psykiatri, for tiden ansatt ved Senter for behandlingsforskning på Oslo universitetssykehus.

Forfatter har fylt ut ICMJE-skjemaet og oppgir ingen interessekonflikter.

Lege og epidemiolog Richard Doll reddet millioner av menneskeliv med sin forskning på sammenhengen mellom røyking og lungekreft. Dersom smarttelefonen viser seg å være den nye sigaretten, er det viktig å lære av Dolls forskning for å forstå dens effekt på vår psykiske helse.

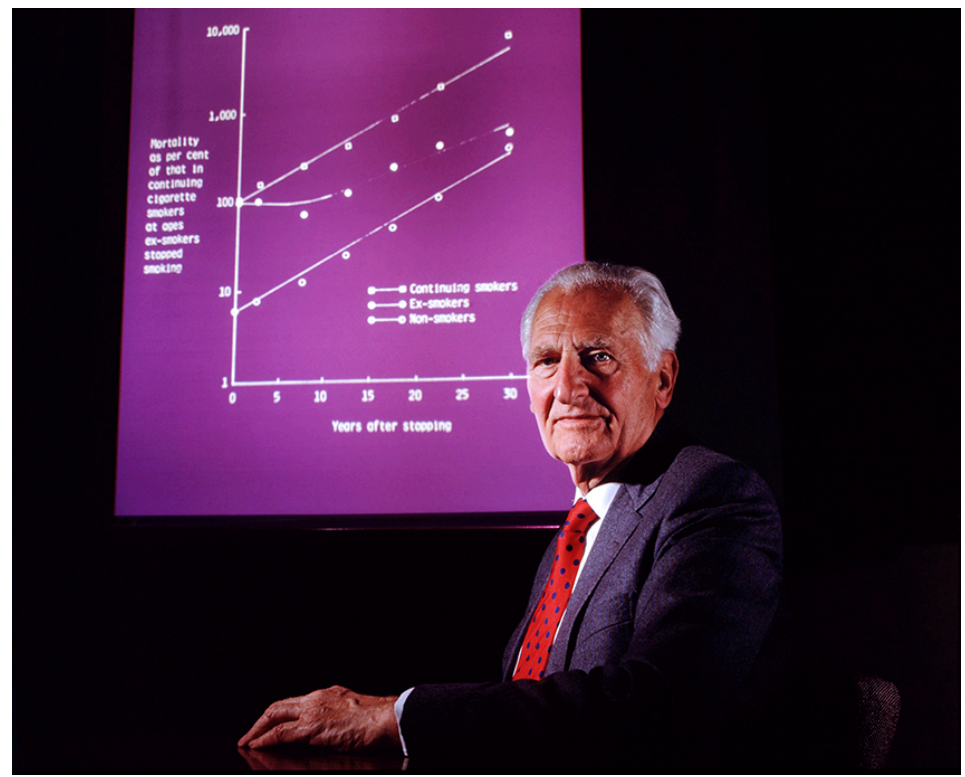

Richard Doll (1912-2005) fotografert 1989 med en av hans grafer over røykeres mortalitetsrate. Foto: Science Photo Library / NTB

Det er en rekke interessante paralleller mellom sigarettens rolle før og smarttelefonens rolle nå. Der alle før i tiden brukte pekefingeren til å støtte sigaretten mens de ventet på det evig forsinkede toget (noen ting forandrer seg aldri), bruker alle i dag pekefingeren til å navigere mellom apper og nettaviser mens man fryser på perrongen. Begge er noe man kan bedrive tiden med når man ellers ville kjedet seg eller mangler stimuli.

I situasjoner der man tidligere ville tent seg en røyk, for eksempel etter sex, tar mange i dag opp mobiltelefonen for å scrolle seg til ro eller belønne seg selv. Men også som en flukt fra 
vanskelige situasjoner deler de samme funksjon; begge kan fylle rommet der det subtile sosiale ubehaget ellers tar plass, sittende alene på en fest eller i et venterom med fremmede. Der man tidligere kunne se opptatt ut ved å rulle seg en sigarett og røyke den med selvsikker gest, og dermed både fremstå og føle seg mindre ensom, plukker mange nå frem mobiltelefonen som sitt skjold mot ensomheten (Ensom? - Nei, ikke jeg, veldig opptatt!).

Også på sjekkingens arena har telefonen tatt over. I dag sitter man hjemme og sveiper til høyre, mens man tidligere kunne lene seg på den alltid sikre ice-breakeren «Har du fyr?». Og røykernes fellesskap, ofte avskjermet fra de andre gjennom sikker dominans på balkongen, der praten alltid går litt friere og sjekkingen litt lettere, eller i markerte hjørner i skolegården, finnes i dag bare som en blek kopi i de sosiale medienes lukkede grupper. Begge tilbyr også det samme kortvarige, men helt nødvendige dopamintilskuddet mellom alle dagens nødvendige plikter, og kan gi en gnist av lys i en ellers monoton, mørklagt hverdag.

Telefonen og sigaretten fyller altså samme behov i de samme situasjonene; begge tilbyr flukt og belønning gjennom trøst, tilhørighet og trygghet

Telefonen og sigaretten fyller altså samme behov i de samme situasjonene; begge tilbyr flukt og belønning gjennom trøst, tilhørighet og trygghet. Videre er ikke likhetene bare kvalitative, men også kvantitative. For de har også til felles sitt altomfattende nærvær i enhver situasjon - sigaretten før, smarttelefonen nå. Det samme stigmaet som tidligere tilfalt de som ikke røykte, tilfaller i dag de som ikke eier en smarttelefon - hvis de fortsatt finnes.

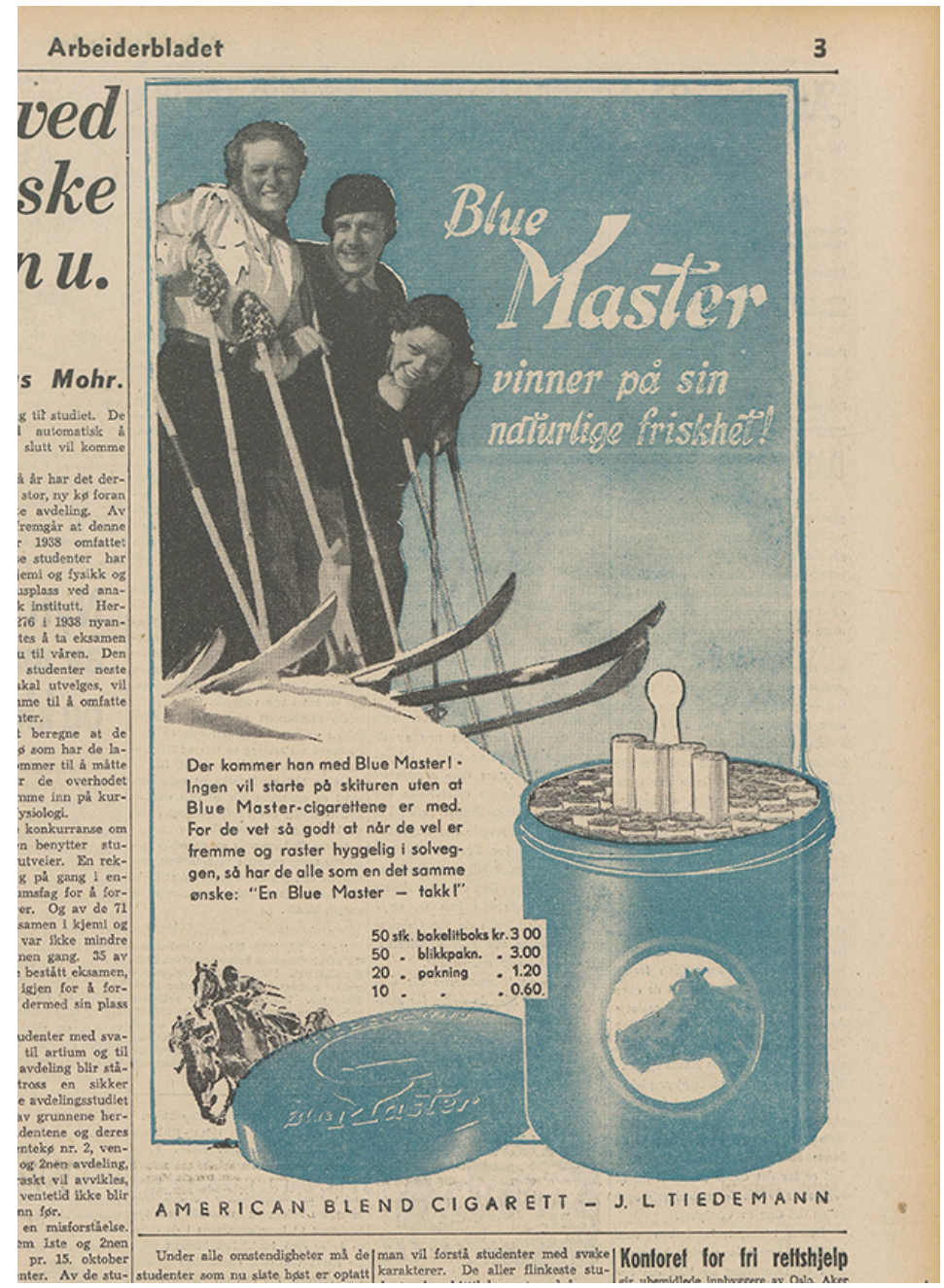

Norsk reklame i Bergens Arbeiderblad 16. mars 1940. Faksimile: Nasjonalbiblioteket

Det aller viktigste telefonen og sigaretten har til felles har vi likevel ikke berørt: potensialet for avhengighet. Enhver kan ha nytte av å tenke igjennom sitt eget forhold til smarttelefonen med Verdens helseorganisasjons kriterier for avhengighet in mente (1): Har 
du sterk lyst til å bruke telefonen; kan du ofte føle et nærmest tvangspreget behov for å bruke telefonen; har du noen ganger hatt problemer med å begrense bruken (for eksempel slik at det har påvirket døgnrytmen); forsøkt å redusere bruken uten å lykkes; utsatt eller unnlatt å gjøre andre ting fordi du brukte opp tiden på telefonen; eller bruker du stadig mer tid på telefonen på bekostning av andre gleder (som den romanen du aldri får lest)? I så fall er du kanskje allerede avhengig.

\section{Et tankeeksperiment}

La oss gjøre et tankeeksperiment: Hvis du fikk vite at en stor kasus-kontroll-studie antydet at daglig bruk av smarttelefon gir økt risiko for demens, og at debut av demenssymptomer kommer 15 år tidligere hos dem som bruker telefonen mest - ville du da lagt fra deg telefonen? Eller ville du sagt som de fleste røykere gjorde da Richard Doll (1912-2005) og Austin Bradford Hill (1897-1991) publiserte sin første banebrytende studie om røyking og lungekreft, at disse tallene høres usannsynlige ut, at det må være snakk om korrelasjon, ikke kausalitet eller at fordelene uansett oppveier risikoen dersom det skulle vise seg å være riktig?

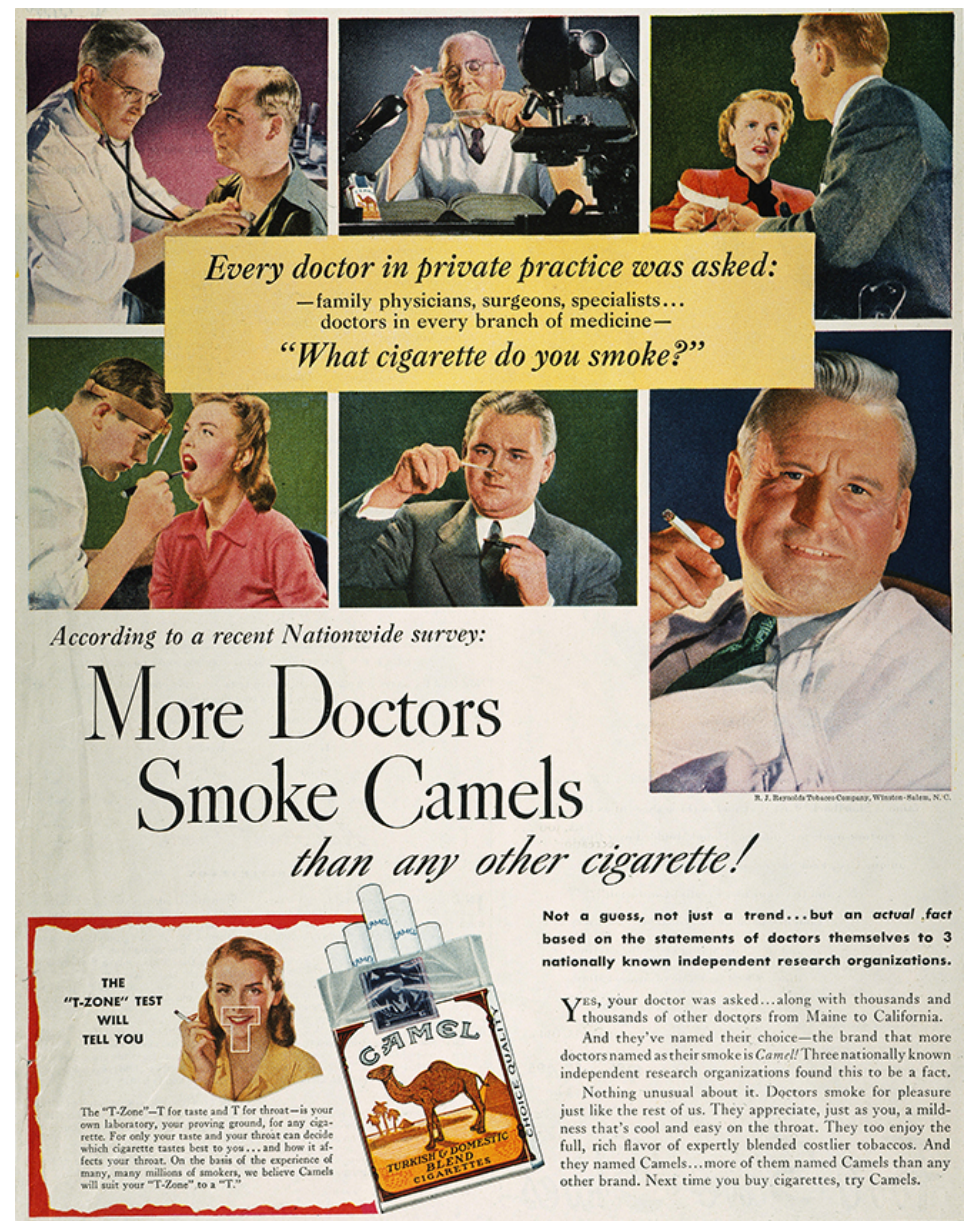

Amerikansk reklame fra 1950. Faksimile: Granger Historical Picture Archive / Alamy Stock Photo

Hvis din første respons er at en slik sammenheng umulig kan stemme, hva er din skepsis egentlig begrunnet i? Er det bare sunn skepsis og et sunt kritisk blikk på all ny forskning, eller kan det være at din egen avhengighet gjør at du vurderer disse påstandene mer kritisk enn du vurderer annen forskning - fordi du ikke vil at det skal være sant? Heldigvis kan du puste lettet ut og sjekke telefonen (kanskje uansett på tide, hvis du ikke allerede har gjort det), for ingen forskning har vist en sammenheng mellom bruk av smarttelefon og kognitiv svikt - ennå.

\section{Mannen uten nobelpris}

For å forstå hvorfor vi bør lære av Richard Doll i denne sammenhengen, må vi først forstå hvilke formidable problemer han sto overfor og hvordan han løste dem. I 1948 bestemte 
han seg for å forsøke å finne årsaken til det sterkt økende antallet pasienter som hadde dødd av lungekreft de siste 25 årene. Han spurte derfor 1732 lungekreftpasienter på 20 ulike sykehus i London om alle slags forskjellige vaner, uvaner og livsforhold. Studien ble publisert i 1950, og etter Dolls mening var tallenes tale krystallklar (2). Han fant det overveiende sannsynlig at røyking var forklaringen på økningen av lungekreft, spesielt på grunn av en klar dose-respons-effekt.

Frem til dette hadde Doll selv vært en ivrig røyker, men overbevist av egne resultater bestemte han seg for å slutte. Det var han imidlertid ganske alene om. I det store og hele ble studien oversett, og til dels motarbeidet av aktører med sterke økonomiske interesser. I 1954 publiserte Doll imidlertid en ny studie, og denne gangen gjorde han noe nytt og genialt. Han skjønte at for å overvinne skepsisen til at noe nesten alle gjorde og hadde gjort $\mathrm{i}$ mange år, virkelig kunne være så skadelig, måtte han vise det på en spektakulær måte. Hvis han kunne vise at selv leger - som på den tiden ble sett på som en mer hardfør og mindre dødelig variant av menneskeslekten (noen ting har forandret seg) - også kunne bli syke og dø av røyking, hadde han et håp om å bli trodd. Et annet problem med den forrige studien, en kasus-kontroll-studie, var at den var retrospektiv. Derfor sendte han nå ut et spørreskjema til rundt 40 ooo britiske leger om deres røykevaner, og fulgte dem deretter i fire år. Dermed hadde han gjennomført medisinens første store prospektive kohortstudie.

De fleste er enige om at smarttelefonen i dag er et nødvendig gode, en berikelse av livet og en forenkling av tilværelsen. Samtidig oppstår det en ubestemmelig følelse av ubehag hos de fleste av oss som bruker den ofte

Gjennom dette designet kunne han endelig få svar på spørsmålet: Hva dør røykerne av? Studien ble publisert i 1954, og i løpet av disse fire årene døde 789 av legene, hvorav lungekreft var årsaken til 36 av tilfellene (3). I seg selv høres kanskje ikke disse tallene sjokkerende ut, men avansert statistisk analyse etterlot ingen tvil: Røyking dreper. Da Doll fulgte opp studien i 1994, altså 40 år senere, var tallene enda tydeligere (4). Nesten halvparten av legene var døde, 883 av lungekreft, og Doll mente at de tidligere studiene hans sågar hadde undervurdert hvor skadelig røykingen hadde vært for legene. Den samlede betydningen av denne studien er vanskelig å overvurdere, og det er derfor blitt kalt «skandaløst» at Doll aldri ble tildelt nobelprisen for sin innsats (5).

\section{Fisken i vannet}

Doll sto overfor samme utfordring i 1949 som vi gjør i dag angående smarttelefonens innvirkning på våre liv, nemlig at fisken ikke ser vannet den svømmer i. Tenk hvor vanskelig det var å påvise den tette kausale sammenhengen mellom lungekreft og røyking i en verden der nesten alle røykte, spesielt siden også ikke-røykere ble rammet av lungekreft. Det virket derfor ikke intuitivt riktig at røyking kunne være årsaken, noe heller ikke Doll trodde da han igangsatte forskningen. I et intervju sier han selv: «Sigarettrøyking var så vanlig og hadde vært det i så lang tid, at det var vanskelig å tenke seg at det kunne være assosiert med noen sykdom» (6). Dolls arbeidshypotese var derfor at det måtte skyldes den $\emptyset$ kende luftforurensningen i London. 


\section{Bơr 16-åringen begynne med robakk?}

Kan 2 min. si meg om det er farlig â royke năr en lkke er eldre enn 16 âr? Kan jeg få kreft eller andre sjukdommer av det?

16 âr.

SVAR: De fleste leger mener at bare det lkke blir for mye, kan de fleste røyke uten a ta noen skade av det. Og det er også en vanlig mening at sjansen for at royking skal gjøre skade er størst når en begynner for tidlig. Legene kan ikke si noe mer bestemt av generell art. Det er ikke uvanlig at 16-åringer går 1 gang.

Arbeiderbladet den 25.juli 195o. Faksimile: Nasjonalbiblioteket

Den samme holdningen hadde man også i Norge. En nysgjerrig leser som spør avisen Arbeiderbladet den 25. juli 1950 om det er greit for 16-åringer å røyke, fikk følgende svar: «De fleste leger mener at bare det ikke blir for mye, kan de fleste røyke uten å ta noen skade av det. Og det er også en vanlig mening at sjansen for at røyking skal gjøre skade er størst når en begynner for tidlig. Legene kan ikke si noe mer bestemt av generell art. Det er ikke uvanlig at 16-åringer går i gang (7).» Kunne noe slikt stått på trykk i dag? Kanskje, hvis man bytter ut «røyking» med «bruk av smarttelefon».

\section{Den ubestemmelige følelsen}

De fleste er enige om at smarttelefonen i dag er et nødvendig gode, en berikelse av livet og en forenkling av tilværelsen. Samtidig oppstår det en ubestemmelig følelse av ubehag hos de fleste av oss som bruker den ofte, en slags oppmerksomhetens fragmentering, en kløe i konsentrasjonsevnen som aldri blir helt borte, en vedvarende følelse av å ikke være der det skjer. Dette ubehaget gjør at de fleste på et eller annet tidspunkt legger en plan for å redusere bruken, kanskje til og med sletter en app, ofte bare for å installere den på nytt tre dager senere og bruke den mer enn noen gang før.

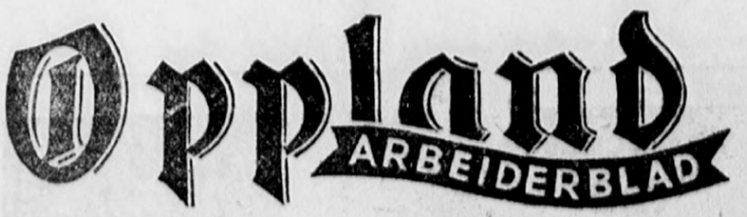

\section{Tobakks-vanene ikke endret Trass i den foruroligende melding om røyking og lungekreft}

Men noen svake sjeler har tatt skrekk og har søkt lege

Fra Oppland Arbeiderblad 14. november 1953. Faksimile: Nasjonalbiblioteket

Dette udefinerte kollektive ubehaget bør tas på alvor. Å ta det på alvor er å prøve å forstå det, og for å forstå det, må vi lære av forskningen til Richard Doll. 
Man ser riktignok en viss økning i psykiske plager hos yngre kvinner, som også er de største forbrukerne av smarttelefon, noe som kan indikere en mulig dose-respons-effekt allerede. Men etter å ha gått igjennom noe av den forskningen som per i dag finnes på farene ved daglig bruk av smarttelefon, er jeg foreløpig ikke spesielt bekymret for langtidseffekten (8). Smarttelefonbruk er jo så vanlig, og har allerede vært det i lang tid. Stigningen i psykiske plager hos yngre kvinner skyldes sikkert andre forhold. På den annen side, det samme trodde Richard Doll i $1949 \ldots$

LITTERATUR:

1. WHO. WHOs kriterier for avhengighetssyndrom.

https://www.who.int/substance_abuse/terminology/definition1/en Lest 14.1.2021.

2. Doll R, Hill AB. Smoking and carcinoma of the lung; preliminary report. BMJ 1950; 2: 739-48.

[PubMed][CrossRef]

3. Doll R, Hill BA. Smoking and carcinoma of the lung: preliminary report. BMJ 1954; 1:1451-5.

[PubMed][CrossRef]

4. Doll R, Peto R, Wheatley K et al. Mortality in relation to smoking: 40 years' observations on male British doctors. BMJ 1994;309: 901-11. [PubMed][CrossRef]

5. Seed T. Richard Doll: The link between smoking and lung cancer. I: Thompson G, red. Pioneers of medicine without a Nobel Prize. London: Imperial College Press, 2014.

6. Le Fanu J. The rise \& fall of modern medicine. Great Britain: Little, Brown Book Group, 2011.

7. Arbeiderbladet 25.7.1950, side 2.

https://www.nb.no/items/503910a75a182c813e775e896dfozbc9?page=o\&searchTextr\%C3\%B8yking\%2osunt Lest 14.1.2021.

8. Bailin A, Milanaik R, Adesman A. Health implications of new age technologies for adolescents: a review of the research. Curr Opin Pediatr 2014; 26: 605-19. [PubMed][CrossRef]

Publisert: 22. mars 2021. Tidsskr Nor Legeforen. DOI: 10.4045/tidsskr.20.1017

(C) Tidsskrift for Den norske legeforening 2020. Lastet ned fra tidsskriftet.no 